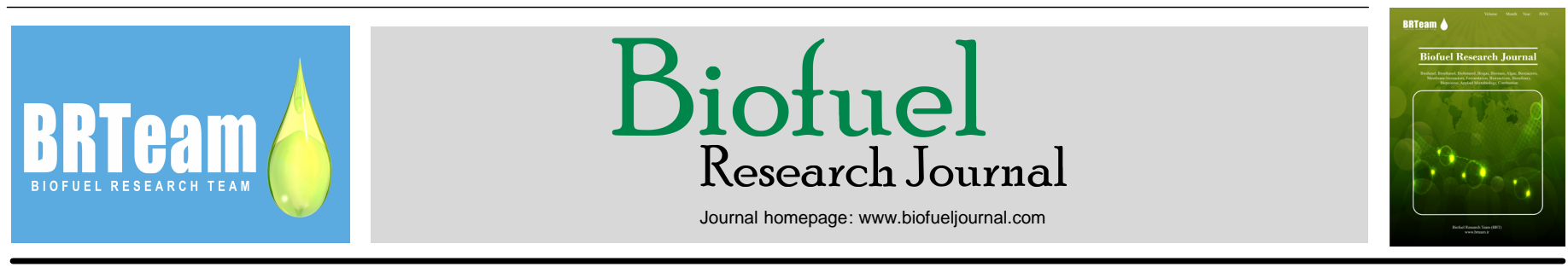

Review Paper

\title{
Recent trends on techno-economic assessment (TEA) of sugarcane biorefineries
}

\author{
Mohsen Ali Mandegari†, Somayeh Farzad ${ }^{\dagger}$, Johann F. Görgens* \\ Department of Process Engineering, University of Stellenbosch, Private Bag X1, Matieland, 7602, South Africa.
}

\section{HIGHLIGHTS}

$>$ Sugar mills have opportunities to become economically_viable biorefineries.

$>$ TEA of biofuels, biochemical, and biopolymers form sugarcane were reviewed.

$>$ TEA is vital to sift through the product options to define investment opportunities.

$>$ More research is required for biochemical and

biopolymer production scenarios.

\section{GRAPHICAL ABSTRACT}

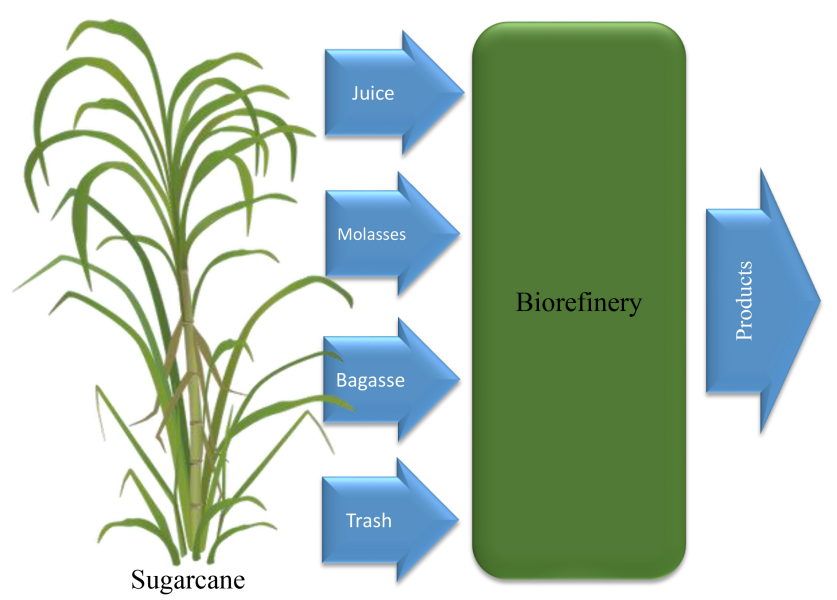

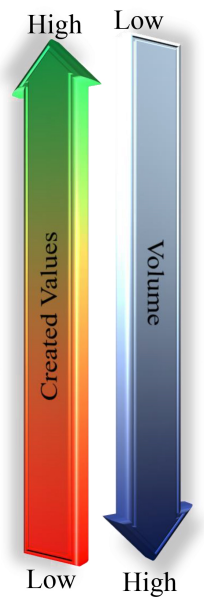

\section{ARTICLE INFO}

\section{Article history:}

Received 30 June 2017

Received in revised form 5 August 2017

Accepted 17 August 2017

Available online 1 September 2017

\section{Keywords:}

Sugarcane

Biorefinery

Biofuel

Biochemical

Biopolymer

Techno-economic assessment

\begin{abstract}
Sustainability challenges, e.g., climate change, resource depletion, and expanding populations, have triggered a swift move towards a circular bio-economy which is expected to evolve progressively in the coming decades. However, the transition from a fossil fuel-based economy to a bio-based economy requires the exploitation of scientific innovations and step changes in the infrastructure of chemical industry. Biorefineries have been extensively investigated for biofuel production from first and second generation feedstocks, whereas some research activities have been conducted on production of biochemical and biopolymers from renewable resources. Techno-economic evaluation of diverse technologies for production of biofuels and biochemical is a crucial step for decision making in the development of bio-economy. This contribution focuses on the economic studies carried out on biorefineries converting sugarcane bagasse, due to its availability and importance in the South African context, into valueadded products. Recent studies on biofuel production via biochemical pathway, e.g., ethanol, butanol, or thermochemical pathway, e.g., methanol and bio jet fuel as well as production of biochemicals with high market demands and diverse applications such as lactic acid, succinic acid, and xylitol have been briefly reviewed. In addition, an overview on the production of biopolymers such as polyl-lactic acid and bio-based monomers, i.e., butanediol, from sugarcane bagasse is reported.
\end{abstract}

* Corresponding author at: Tel.: +27 218083503

E-mail address: jgorgens@sun.ac.za

${ }^{\dagger}$ These authors contributed equally.

Please cite this article as: Mandegari M.A., Farzad S., Görgens J.F. Recent trends on techno-economic assessment (TEA) of sugarcane biorefineries. Biofuel Research Journal 15 (2017) 704-712. DOI: 10.18331/BRJ2017.4.3.7 


\section{Contents}

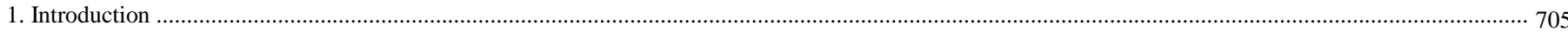

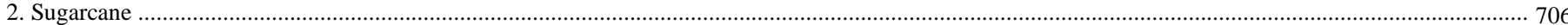

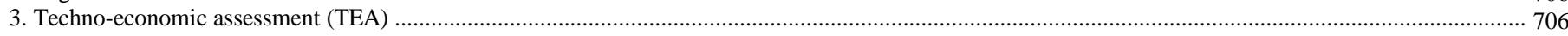

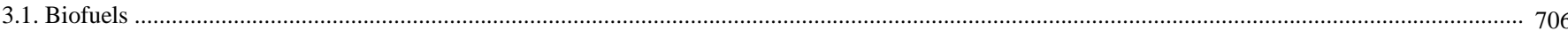

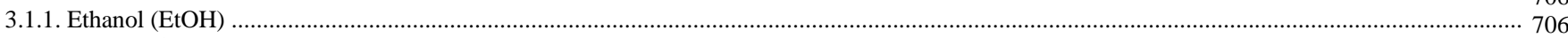

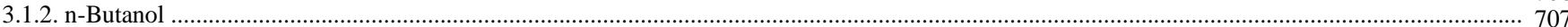

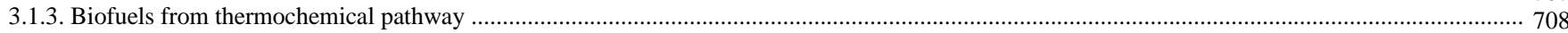

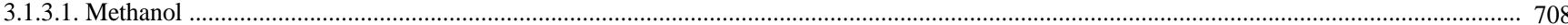

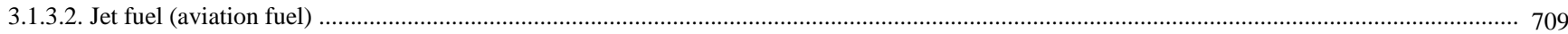

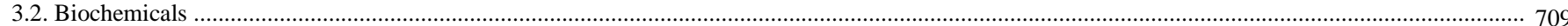

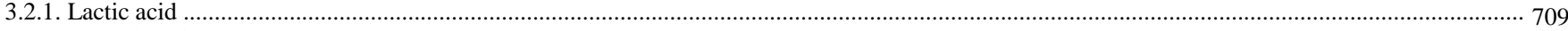

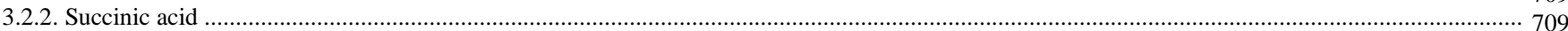

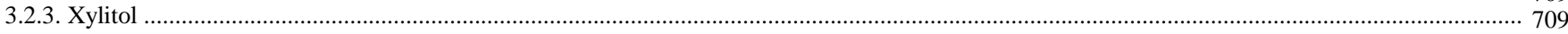

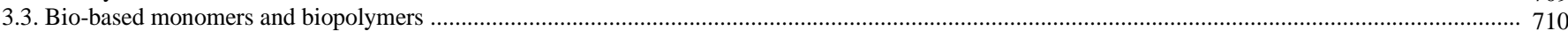

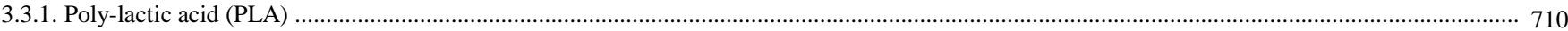

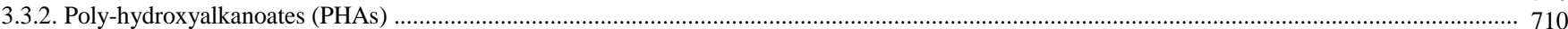

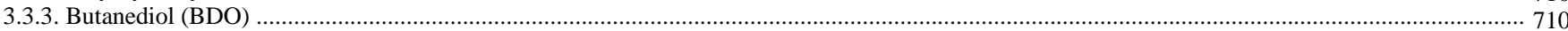

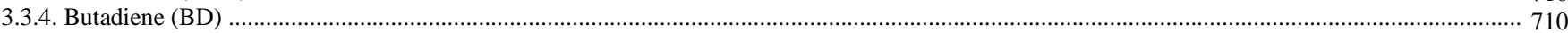

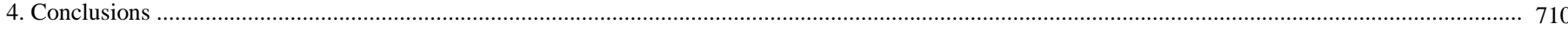

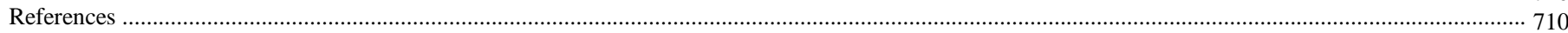

\begin{tabular}{|c|c|}
\hline \multicolumn{2}{|l|}{ Abbreviations } \\
\hline $\mathrm{ABE}$ & Acetone, butanol and ethanol \\
\hline $\mathrm{BD}$ & Butadiene \\
\hline $\mathrm{BDO}$ & Butanediol \\
\hline $\mathrm{DM}$ & Dry mass \\
\hline $\mathrm{EtOH}$ & Ethanol \\
\hline FP-H & Fast pyrolysis followed by hydroprocessing \\
\hline $1 \mathrm{G}-2 \mathrm{G}$ biorefinery & First and second generation biorefinery \\
\hline $1 \mathrm{G}$ biorefinery & First generation biorefinery \\
\hline FT & Fisher-Tropsh \\
\hline G-FTs & Gasification followed by Fischer-Tropsch synthesis \\
\hline HD-PE & High density polyethylene \\
\hline HTL & Hydrothermal liquefaction \\
\hline IRR & Internal rate of return \\
\hline LA & Lactic Acid \\
\hline LLD-PE & Linear low density polyethylene \\
\hline LD-PE & Low density polyethylene \\
\hline $\mathrm{MeOH}$ & Methanol \\
\hline MTBE & Methyl-tert-butyl ether \\
\hline MESP & Minimum ethanol selling price \\
\hline PA & Polyacetylene \\
\hline PBR & Polybutadiene \\
\hline PBS & Polybutylene succinate \\
\hline PEG & Polyethylene glycol \\
\hline PET & Polyethylene terephthalate \\
\hline PHAs & poly-hydroxyalkanoates \\
\hline PLA & Poly lactic acid \\
\hline PS & Polystyrene \\
\hline PVA & Polyvinyl acetate \\
\hline PVC & Polyvinyl chloride \\
\hline $2 \mathrm{G}$ biorefinery & Second generation biorefinery \\
\hline SBR & Styrene-butadiene rubber \\
\hline TEA & Techno-economic assessment \\
\hline
\end{tabular}

\section{Introduction}

In recent years, environmental concerns, energy security issues, and global climate change have driven the development of biobased economy, where biorefineries and bio-products are identified as key pathways to decrease fossil fuel consumption. Different biorefinery routes (thermochemical and biochemical) for the production of biofuels and chemicals have been developed. Among biofuels, ethanol and butanol have been extensively studied, whereas bioethanol production has been used in large scale in countries such as Brazil (from sugarcane) and the USA (from corn). First-generation (1G) bioethanol derived from food crops, i.e., corn, wheat, sugar beet, as well as oil seeds, has been widely used for vehicle fuels, lowering net carbon dioxide emissions compared to fossil fuels. However, increasing demands of $1 \mathrm{G}$ biofuels has led to food $v s$. fuel concerns (Bezerra and Ragauskas, 2016) and consequently secondgeneration $(2 \mathrm{G})$ biofuels from lignocellulosic biomass, have received a huge deal of interest worldwide to overcome this challenge. Moreover, the co-production of integrated $1 \mathrm{G}-2 \mathrm{G}$ biorefinery for production of fuel, food, feeds, and value-added products have been investigated by many researchers (FitzPatrick et al., 2010).

In the global trend towards an increased use of renewable feedstocks, sugarcane, as a crop, has become more important. Sugarcane bagasse is one of the most commonly examined lignocellulosic materials due to its relative abundance, potential lower supply cost, and avoidance of land use competition with food crops (Farzad et al., 2017a). Sugarcane biorefineries convert sugar syrups, molasses, bagasse, and harvesting residues into a plethora of bio-products. The main challenge of $2 \mathrm{G}$ biorefineries is their ability to compete with fuel/chemical production through conventional pathways (Baeyens et al., 2015). In order to develop economically-viable biorefineries, production of value-added chemicals along with fuel is investigated by academics. Furthermore, interest in bio-based chemicals has risen due to increasing environmental problems and climate change concerns associated with the growing use of fossil resources (Bos and Sanders, 2013; Biddy et al., 2016). Bioethanol is the main product generated from sugar-based platforms, followed by n-butanol, acetic acid, and lactic acid, these occupy much smaller but still significant shares of the market though. In addition to those, Xylitol, sorbitol, and furfural, also generated through chemical conversion of sugars, have considerable markets too while these products have no petrochemical alternatives (Taylor et al., 2015). It should be mentioned that the $2 \mathrm{G}$ production of these products are close to commercialization with a few industrial or demonstration practices (Peplow, 2014; Taylor et al., 2015). Aviation fuel has a significant impact on $\mathrm{CO}_{2}$ emission in the transportation sector, therefore, its production from biomass has become the focus of numerous research activities over the course of recent years (Wang and Tao, 2016). Moreover, succinic acid is one of bio-products, reported among the top twelve with near-term deployment potential based on its large projected 
market (Biddy et al., 2016), since it has been identified as a feedstock for higher value products (Shen et al., 2015).

Due to the wide spectrum of possible products from first and second generation feedstocks and the complexity of the processes involved, techno economic assessment (TEA) should be carried out to define the feasibility of the biorefineries. This study aims to represent a concise review on recent TEAs carried out considering different biofuels (e.g., ethanol, butanol, methanol, jet fuel, and Fischer-Tropsch (FT) syncrude), biochemical (e.g., lactic acid, succinic acid, and xylitol), as well as biopolymers (e.g., polylactic acid, polyhydroxyalkanoates, butadiene, and butanediol) from different parts of sugarcane (i.e., juice, molasses, bagasse, and trash). Comparison of available literature will help to identify the areas which require more attention by academic communities.

\section{Sugarcane}

Sugarcane, originated in Asia probably in New Guinea, has a large capacity to convert solar energy into biomass. Most of the rain-fed and irrigated commercial sugarcane is grown between $35^{\circ} \mathrm{N}$ and $\mathrm{S}$ of the equator. The crop flourishes under a long, warm growing season with a high incidence of radiation and adequate moisture, followed by a dry, sunny, and fairly cool but frost-free ripening and harvesting period (www.fao.com). The total cane energy content, excluding ash (about 2-3\%) can be divided into three main parts including juice, fibrous residues (bagasse), and sugarcane agriculture residues, i.e., tops and trashes (Renó et al., 2014). Sugarcane is the main feedstock for sugar production all over the world with about 27 million ha area land used and total commercial world production of about 1900 million tonnes/year (t/y) cane (www.faostat.com). The distribution of sugarcane production around the globe is demonstrated in Figure 1. Brazil is the main producer with $38.8 \%$, followed by India $(18.8 \%)$, China $(6.6 \%)$, Thailand $(5.5 \%)$, and Africa $(5.0 \%)$. The average production rate of sugarcane has increased by about $4 \%$ over the last 10 years, whereas this rate differs among countries.

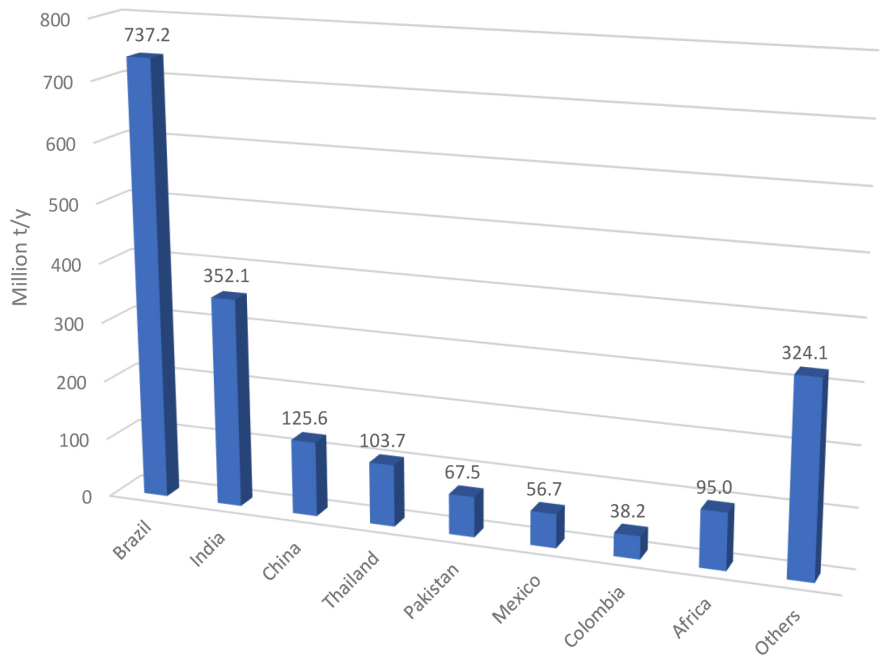

Fig.1. Sugarcane distribution based on countries in the year 2014 (www.faostat.com)

Although characterisation of sugarcane may differ in different seasons and regions, the average characteristics of sugarcane plant are represented in Table1. Dry mass (DM) of bagasse is about $15 \%$ of the total sugarcane weight. In the sugar industry context, bagasse is mostly burnt in boilers, to provide the steam and electricity demands of sugar mills (Mandegari et al., 2017a). Whereas, technical approaches are already available to improve energy efficiency in sugar cane processing, resulting in liberation of surplus bagasse. Furthermore, $7.5 \mathrm{wt} . \%$ of sugarcane is trash which can be collected via green harvesting of the sugarcane (Farzad et al., 2017a) leading to higher available feedstock. Brazil is currently in a transition from burning the whole cane for harvesting to unburned (green) harvest (Dias et al., 2015). Sugarcane bagasse and fibrous residues are typically composed of $39-43 \%$ cellulose, $21-23 \%$ lignin, 25-32\% hemicelluloses, and minor amounts of organic extractives and ash (Oliveira et al., 2013; Clauser et al., 2016), which make them a proper carbon source for valorisation.

Table 1.

General characterization of the sugarcane plant.

\begin{tabular}{llll}
\hline Material & $\begin{array}{l}\text { wt.\% of } \\
\text { sugarcane }\end{array}$ & $\begin{array}{l}\text { Moisture } \\
\text { content }\end{array}$ & Reference \\
\hline Total sugar content & $15 \%$ & - & Dias et al. (2013a) \\
Bagasse & $30 \%$ & $50 \%$ & $\begin{array}{l}\text { Petersen et al. (2014); } \\
\text { Smithers (2014) }\end{array}$ \\
\hline Fibrous residues* & $15 \%$ & $15 \%$ & Smithers (2014) \\
\hline
\end{tabular}

* Fibrous residues refers to brown leaves and green tops. Brown leaves (trash) are 50\% of total residues. Only the brown leaf component of sugarcane harvesting residues will be available by a green-cane-harvesting approach, while the tops (green leaves) will be left in the field to maintain soil fertility (Smithers, 2014; Farzad et al., 2017b).

\section{Techno-economic assessment (TEA)}

To compare the feasibility of biorefineries following the thermochemical or biochemical pathways or biorefineries with different complexity based on the implemented technology, economic performance of each biorefinery should be thoroughly investigated. As common means used in techno-economic assessment, several predefined parameters or objectives (e.g., production cost and rate of return) which represent the techno-economic performance are evaluated and compared for different case studies. The evaluation is carried out by determining some common indicators, i.e., payback period, net present value, fixed capital cost, total manufacturing cost, after-tax rate of return, and break-even price. Some researchers have argued that the conversion of biomass to biofuels is strongly influenced by the cost of the feedstock and the technology used (Lange, 2007). For instance, FT syncrude production is technology dominated, whereas the vegetable-oil-based biofuel production is significantly influenced by feedstock cost (Parajuli et al., 2015). Several examples of techno-economic performance assessments for biofuel generation are available in the literature (Brown, 2015). However, comparison of the results is challenging because different approaches have been implemented by different research works. The available data on TEAs have been summarised based on the products, as follows.

\subsection{Biofuels}

Annually the transportation sector consumes $25 \%$ of the global primary energy and is responsible for the related greenhouse gas emissions Currently, petroleum-derived liquid fuels are the dominant source of energy and biofuels can be appropriate options for their substitution (Bhutto et al. 2016). A summary of the recent TEA studies on conversion of sugarcane to biofuels is represented in Table 2.

\subsubsection{Ethanol (EtOH)}

Ethanol production has received an increasing deal of attention, mostly because of its major environmental benefits. It can be produced from different kinds of renewable feedstock mainly sugarcane (35\%) and corn $(65 \%)$ with world production of 110 billion L in the year 2015 (Chum et al., 2014; Baeyens et al., 2015). The USA, Brazil, and several EU member states have the largest programs promoting bioethanol in the world (Balan et al., 2013; Chum et al., 2014). Since the year 2014, two commercial sugarcane lignocellulosic bioethanol production plants with capacities of 40 and $84 \mathrm{Ml} / \mathrm{y}$ (about $0.4 \%$ of the production capacity in Brazil) have become operational (Chum et al., 2014; Peplow, 2014), while several other projects are still in progress worldwide (Balan et al., 2013).

The biorefinery converting sugarcane residues (bagasse and trash) of an autonomous distillery to ethanol has been studied for Brazil (Seabra et al., 2010) and Colombia (Sánchez and Cardona, 2012) which showed acceptable economic performances. The lignocellulosic ethanol production (i.e., 2G) from extracted residue of $1 \mathrm{G}$ autonomous distillery and 
Table 2.

Recent TEA studies on the sugarcane biorefineries aimed at biofuels production.

\begin{tabular}{|c|c|c|c|c|}
\hline Brazil & Bagasse and trash & $\mathrm{EtOH}$ & 1000 & Seabra and Macedo (2011) \\
\hline South Africa & Bagasse and trash & $\mathrm{EtOH}$ & 300 & Mandegari et al. (2017) \\
\hline Brazil & Cane juice and hemicellulose & $\mathrm{EtOH}$ & 500 & Dias et al. (2013b) \\
\hline Brazil & Cane juice, bagasse, and trash & Butanol & 500 & Pereira et al. (2014) \\
\hline Brazil & Cane juice & Butanol & 500 & Mariano et al. (2013) \\
\hline South Africa & Bagasse and trash & Butanol & 300 & Farzad et al. (2017b) \\
\hline Brazil & Cane juice, bagasse, and trash & Jet fuel / Chemicals & 500 & Alves et al. (2017) \\
\hline Cuba & Bagasse and trash & $\mathrm{EtOH} / \mathrm{MeOH}$ & 1700 & Renó et al. (2014) \\
\hline Brazil & Cane juice, bagasse, and trash & $\mathrm{EtOH} / \mathrm{MeOH}$ & 500 & Albarelli et al. (2015) \\
\hline South Africa & Bagasse & Pyrolysis products & 300 & Nsaful et al. (2013) \\
\hline China / UK & Bagasse & FT / Pyrolysis products & $667^{*}$ & Michailos et al. (2017) \\
\hline
\end{tabular}

* Calculated based on the reported data on bagasse as well as those reported in Table 1 .

integration of 1G-2G have been investigated by Brazilian (Dias et al., 2013b), Cuban (Macrelli et al., 2012; Dias et al., 2013b; Renó et al., 2014) and Colombian researchers (Moncada et al., 2013), where better performances compared with the individual $2 \mathrm{G}$ biorefineries were achieved. Furthermore, different alternatives for annexing a $2 \mathrm{G}$ biorefinery into existing sugar mill in South Africa have been studied (Mandegari et al., 2017a) which proved that annexing biorefinery to the existing mill would improve the economic performance since the feedstock would be cheaper than a standalone biorefinery.

The majority of the produced EtOH worldwide is consumed as transportation fuel, whereas it is an important building block for other advanced biofuels and bio-chemicals as well. Some of the possible products from EtOH are shown in Figure 2. Among the possible products, only a few options have been studied.

\subsection{2. n-Butanol}

Although ethanol is a well-established biofuel for blending with petrol, there is a growing interest in butanol because of its superior fuel properties compared with those of ethanol, including a higher heating value, lower volatility, reduced ignition problems, ease of blending, a higher viscosity, safer to use, and easier distribution (Jin et al., 2011). Butanol is produced from either metabolic pathway, also known as acetone, butanol and ethanol (ABE) fermentation, or chemical synthesis from ethanol (Ndaba et al., 2015).

Although the first option (ABE process) has a long history of research and commercialization, the latter has also gained attention of researchers (Jiang et al., 2015). Techno-economic evaluation of ABE process production from $1 \mathrm{G}$ has been studied by Mariano et al. (2013) and from 2G by Farzad et al. (2017b). The results showed that butanol production by fermentation is economically uncompetitive and technically challenging compared with bioethanol production without improved microorganisms and not traded as a chemical (Mariano et al., 2013; Farzad et al., 2017b). Furthermore, conversion of EtOH into butanol has also been analysed by Dias et al. (2014), which showed that butanol sold as chemical has a limited market and as fuel presents economic constraints. Pereira et al. (2015) assessed two competing technological routes for the production of n-butanol (fermentative and catalytic route) as facilities annexed to a $1 \mathrm{G}-2 \mathrm{G}$ sugarcane biorefinery. Based on their study, ABE process despite its drawbacks performed better than the catalysis of ethanol to n-butanol and co-products (Pereira et al., 2015).

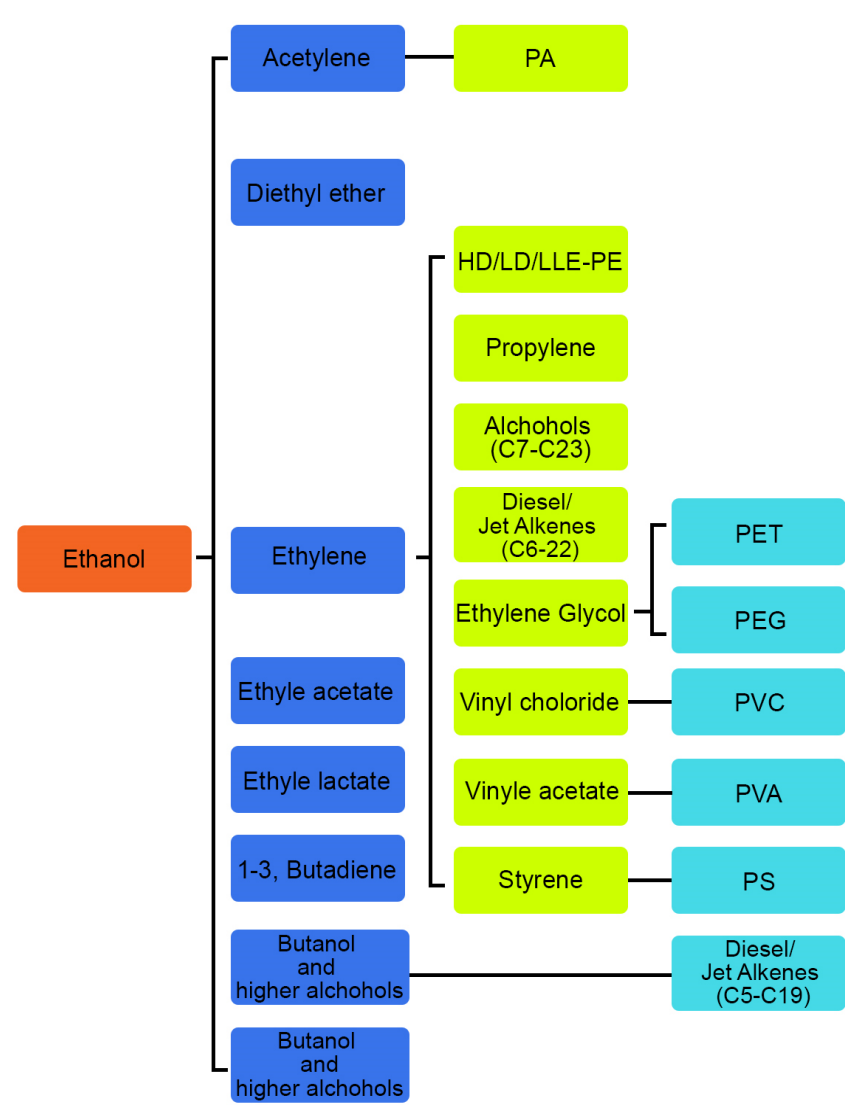

Fig.2. The possible products from EtOH (adapted from Taylor et al. (2015)). 


\subsubsection{Biofuels from thermochemical pathway}

Thermochemical conversion of lignocellulose to fuels/chemicals is an alternative pathway in contrast to biochemical pathway, as demonstrated in Figure 3. Size reduction of biomass along with drying is a preliminary step of this process. Gasification and pyrolysis are the most important technologies of this category followed by liquefaction as a less developed technology.

Gasification is the thermal decomposition of biomass at temperatures up to $1500{ }^{\circ} \mathrm{C}$ to a gaseous mixture of carbon monoxide $(\mathrm{CO})$, hydrogen $\left(\mathrm{H}_{2}\right)$, methane $\left(\mathrm{CH}_{4}\right)$, carbon dioxide $\left(\mathrm{CO}_{2}\right)$, and small amounts of light hydrocarbons using a gasification agent (oxygen, air, steam or their combination). This intermediate product is known as syngas and can be converted into heat and power via combustion, or be catalytically-upgraded to liquid fuels such as ethanol, methanol, gasoline, diesel, jet fuels, etc. (Brown, 2015; Farzad et al., 2016).

Pyrolysis is the thermal decomposition of biomass in the temperature range of $350-700{ }^{\circ} \mathrm{C}$ to produce gases, liquids, and solids. There are four pathways for production of transportation fuels via pyrolysis including slow pyrolysis and upgrading of syngas, fast pyrolysis (FP) \& hydroprocessing, catalytic pyrolysis \& hydroprocessing, and hydropyrolysis \& hydroprocessing (Brown, 2015; Dang et al., 2016).

Solvent liquefaction is the processing of biomass in a pressurized solvent at elevated temperatures to directly produce liquid products. Under relatively mild conditions, the products are sugars and partially deconstructed lignin. At more severe conditions, the products resemble the bio-oil produced from fast pyrolysis, although the product is reported to be more deoxygeated than pyrolysis-derived bio-oil (Brown, 2015; Huang and Yuan, 2015; Tan et al., 2015). There are a number of solvents appropriate for this process, whereas water is frequently used because of its low cost and the ability to directly process wet feedstocks. When water is used as a solvent, the process is known as hydrothermal liquefaction (HTL). The products of solvent liquefaction require further upgrading to finished fuels.
FT syncrude production was not an economically viable option, due to the relatively low volume of production with low cost of syncrude. Recently, Michailos et al. (2017) focused on the feasibility of gasification followed by FT synthesis (G-FTs) route, and fast pyrolysis followed by hydroprocessing (FP-H). Both energetically and financially, G-FTs synthesis found to be the more efficient option, with the payback period of 9 years $(\mathrm{IRR}=11 \%)$ considering USD15/t feedstock cost.

Techno-economic analysis of ethanol production from sugarcane bagasse using a mild liquefaction plus simultaneous saccharification and co-fermentation process has been carried out by Gubicza et al. (2016). They followed the minimum ethanol selling price (MESP) approach and the resulted MESP varied between 50.38 and 62.72 US cents/L which was comparable with the market price.

\subsubsection{Methanol}

Methanol $(\mathrm{MeOH})$ is the simplest alcohol that acts as a hydrogen carrier or storage compound, with the total annual production capacity of 50 million t/y worldwide, of which $75 \%$ is produced from natural gas (Shamsul et al., 2014). Methanol is used as primary feedstock for a large variety of chemicals such as formaldehyde (70\% of the total methanol produced), methyl-tert-butyl ether (MTBE, 20\%), acetic acid, and dimethylether as well as a variety of intermediates exploited in manufacturing of chemicals and materials (Bozzano and Manenti, 2016).

There are several conventional and new processes for the production of biomethanol, such as pyrolysis, gasification, bio-synthesis, electrolysis, and photo electrochemical processes (Shamsul et al., 2014). However, among different technologies, gasification of sugarcane lignocellulosic residues for $\mathrm{MeOH}$ production has been more attractive. Albarelli et al. (2015) evaluated a sugarcane biorefinery producing $\mathrm{EtOH}$ through juice fermentation and $\mathrm{MeOH}$ via gasification of sugarcane lignocellulosic residues and liquid fuel synthesis. The cost analysis showed that the

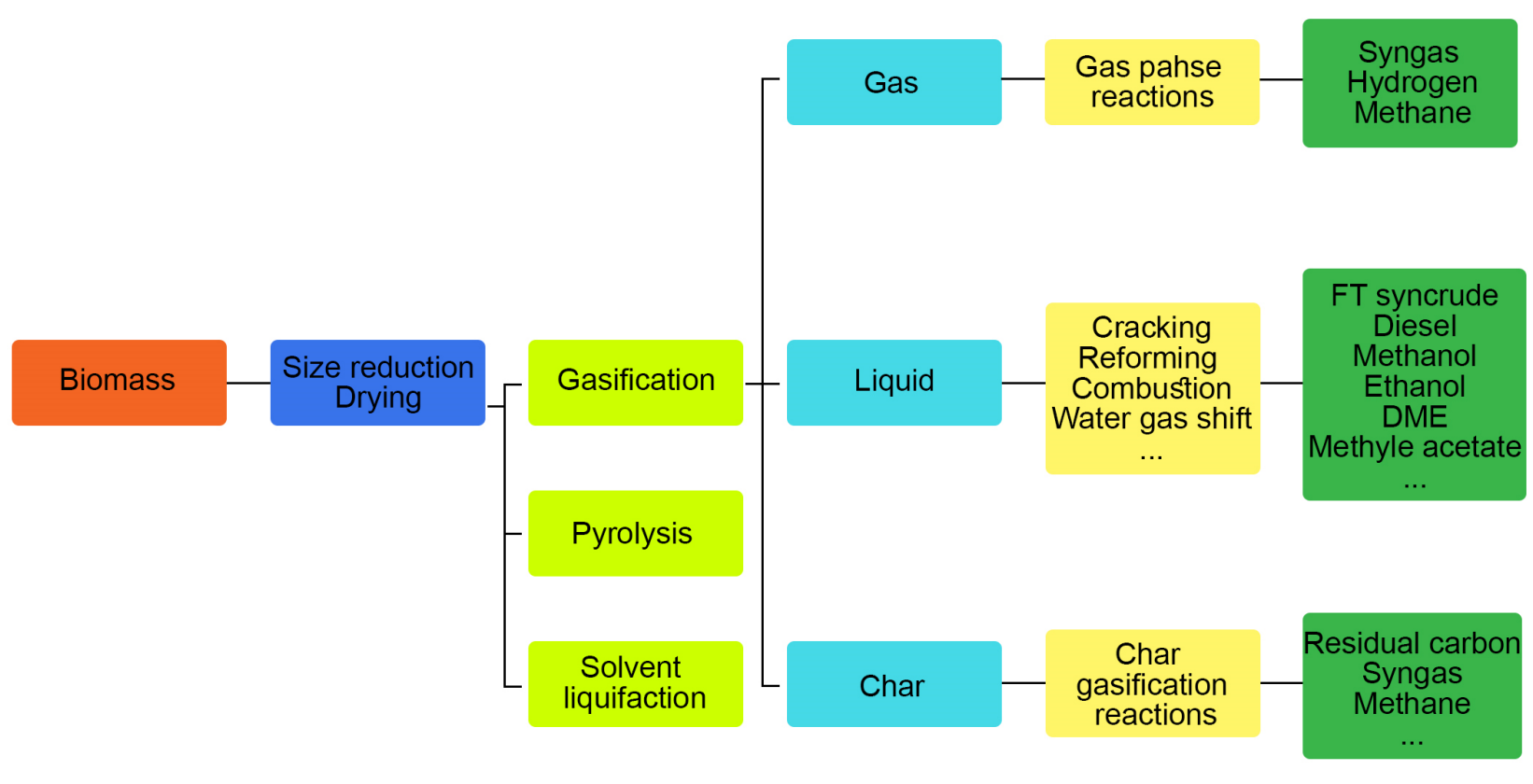

Fig.3. Overall flowchart of the thermochemical pathway for conversion of biomass to fuel/chemicals.

A sugar mill with an annexed $2 \mathrm{G}$ biorefinery has been investigated for methanol, FT syncrude, and bio oil production (Nsaful et al., 2013; Petersen et al., 2015), which showed that the combustion of biomass and electricity production was a more attractive option than applying a pyrolysis plant considering the current pyrolysis technology (Nsaful et al., 2013). Furthermore, investigations by Petersen et al. (2015) and Farzad et al. (2017b) proved that calculated $\mathrm{MeOH}$ production cost was $30 \%$ higher than its then market price. Petersen et al. (2015) and Farzad et al. (2017b) also investigated $\mathrm{MeOH}$ production annexed to a sugar mill. All these studies demonstrated that $\mathrm{MeOH}$ producing scenarios from sugarcane residues are not likely to be economically feasible under the current economic conditions (low oil price), without government subsidies (Albarelli et al., 2015). 


\subsubsection{Jet fuel (aviation fuel)}

Since aviation is responsible for $12 \%$ of the $\mathrm{CO}_{2}$ emissions of all transportation sectors, a new alternative within the jet-fuel production chain could significantly affect the sustainability of the transportation sector (Alves et al., 2017). Bio jet fuel production technologies are at an early stage of development when compared with petrochemical processes. In general, sugarcane components (sucrose/molasses/bagasse/trash) can be converted into bio jet fuel via two pathways, 1: EtOH or butanol production and its upgrading into jet fuel (alcohol-to-jet; applicable for $1 \mathrm{G}$ and $2 \mathrm{G}$ ) and 2: gasification/pyrolysis of biomass residues and upgrading into jet fuel (applicable for 2G only) (Mawhood et al., 2016; Wang and Tao, 2016). Direct sugars to hydrocarbons is also an applicable pathway which was investigated by a joint venture between the companies Amyris and Total. The first commercial plant of this technology, has been operational since December 2012 (Mawhood et al., 2016) in Brazil and the renewable jet fuel produced by the process from a sugarcane feedstock has been used in an Embraer E195 jet operated by the Azul Brazilian Airline (Wang and Tao, 2016).

Various studies have assessed the techno-economic feasibility of bio jet fuel production, covering a broad scope of feedstocks, technologies, and geographical regions (Alves et al., 2017). Although several research activities have been published about $1 \mathrm{G}-2 \mathrm{G}$ generation of bio jet fuel (KleinMarcuschamer et al., 2013; Diederichs et al., 2016; Alves et al., 2017; Santos et al., 2017), the number of studies considering sugarcane as feedstock is limited.

In addition, upgrading lignin to bio jet was found to increase the complexity of the process without leading to a major reduction in the minimum selling price of the product. It is worth noting that, even considering premium fees, an integrated $1 \mathrm{G}-2 \mathrm{G}$ bio jet fuel from sugarcane did not achieve a minimum selling price competitive with the current fossil fuel prices (Santos et al., 2017) and it was 2-4 folds higher than the market prices (Diederichs et al., 2016). Techno-economic comparison of bio jet fuel production from lignocellulose, vegetable oil, and sugar cane juice $(1 \mathrm{G}-2 \mathrm{G})$ conducted by Diederichs et. al. (2016) proved G-FTs as the best $2 \mathrm{G}$ process

\subsection{Biochemicals}

Production of chemicals from renewable resources offers a promising opportunity to reduce petroleum dependence, and improve the overall economics and sustainability of an integrated biorefinery. Overall, in petroleum refineries, $15 \%$ of the entire barrel of oil is consumed for the production of chemicals, whereas chemicals account for nearly $50 \%$ of the refinery profits (Biddy et al., 2016). During the last decade, biochemicals have gained the attention of the researchers and investors because of their respective environmental benefits and economic profitability (Biddy et al., 2016). In the following sub-sections, some remarkable techno-economic studies of sugarcane biorefineries for production of biochemicals are reviewed. The most recent TEA studies on conversion of sugarcane to biochemical/biopolymers are tabulated in Table 3 .

\subsubsection{Lactic acid}

Lactic acid (LA) is the most frequently occurring carboxylic acid in nature, which is globally applied in food, pharmaceuticals, personal care products, industrial uses, and polymers (poly-lactic acid; PLA). LA can be produced from both hexoses and pentoses through homofermentative and hetrofermentative pathways, implementing different microorganisms (Gao et al., 2011). Most commercial production of LA is through microbial fermentation of $1 \mathrm{G}$ feedstocks (carbohydrates). However, there are a few examples of LA production plant form $2 \mathrm{G}$ feedstocks (Biddy et al., 2016). Corbion ${ }^{\circledR}$, produces LA in a gypsum-free process from $2 \mathrm{G}$ feedstocks (Castro-Aguirre et al., 2016).

The results of a TEA study on LA production from sugarcane bagasse and trash, proved that utilization of the whole biomass (pentose and hexoses) for LA production annexed to a sugar mill, through homofermentative pathway was an economically attractive option (Mandegari et al., 2017b). However, further research particularly evaluating the effects of different microorganisms on economic viability of PLA production is necessary.

\subsubsection{Succinic acid}

Succinic acid $\left(\mathrm{C}_{4} \mathrm{H}_{6} \mathrm{O}_{4}\right)$ is a linear saturated di-carboxylic acid, considered as a building block for various chemicals, such as personal care products and food additives (used in the food and beverage industry as an acidity regulator), or bio-polymers (for example polybutylene succinate; PBS), plasticizers, polyurethanes, resins, and coatings (Taylor et al., 2015). Although, it is predominantly produced from butane through catalytic hydrogenation of maleic acid or maleic anhydride, its production via fermentation is already implemented by a number of industries, such as Bioamber and Reverdia, while several other companies, such as Myriant, BASF, and Purac, are constructing or are about to operate commercial-scale bio succinic acid plants (Koutinas et al., 2014). Bio-based succinic acid is most commonly produced through low $\mathrm{pH}$ yeast or bacterial fermentation.

Production of succinic acid from sugarcane bagasse has been investigated by Borges and Pereira, where they reported high conversion yields from sugarcane bagasse hydrolysate (Sindhu et al., 2016). In addition, it has been reported that the implementation of ultrasound pretreatment and hydrolysis of sugarcane bagasse led to succinic acid yields as high as $79 \%$ (Sindhu et al., 2016). There are a few techno-economic analyses on succinic acid production from glycerol (Koutinas et al., 2014) or corn stover as well (Luo et al., 2010).

\subsubsection{Xylitol}

Xylitol, pentahydroxypentane $\left(\mathrm{C}_{5} \mathrm{H}_{12} \mathrm{O}_{5}\right)$, is a sugar alcohol with diverse applications, i.e., sweetener (food and pharmaceutical industries), food preservative agent, antioxidant, moisturizer, stabilizer, and freezing point reducer (Mohamad et al., 2015). Xylitol is industrially-produced from xylan (a hemicellulose) extracted from hardwoods or corncobs, which is hydrolyzed into xylose and then hydrogenated into xylitol in the presence of a catalyst (Taylor et al., 2015). The biochemical/bioprocess alternative, with microbial conversion of xylose to xylitol, has also gained interests partly due to the "natural" status of products from this route. Due to its application as a diabetic sweetener, its production from biomass has gained an increasing deal of attention and different microorganisms have been developed for its production. The most commonly investigated biomass for xylitol production include corn cobs, sugarcane bagasse, and rice straw, whereas oil palm, Eucalyptus wood, and corn leaves have also been examined (Mohamad et al., 2015). Although several microorganisms have been developed for xylitol production, fermentability of lignocellulosic streams and expensive separation of xylitol from fermentation broth are the technological areas which require further research.

Production of xylitol from sugarcane bagasse via the biochemical/microbial route has been investigated using dilute acid pretreatment, where post hydrolysis of dilute acid pre-treated hydrolysate

Table 3.

Recent TEA studies conducted on sugarcane with an aim to produce biochemicals/biopolymers.

\begin{tabular}{llllc}
\hline Location & Feedstock/s & Product/s & Capacity (t cane/h) & Reference \\
\hline Colombia & Bagasse / Molasses & EtOH/PHB & 200 & Moncada et al. (2013) \\
South Africa & Bagasse and trash & EtOH/Butadiene & 300 & Farzad et al. (2017a) \\
South Africa & Bagasse and trash & EtOH/Lactic acid & 300 & Mandegari et al. (2017) \\
Argentina & Bagasse (hemi fraction) & Furfural/Xyliltol & NA & Clauser et al. (2016) \\
Brazil & Molasses / Sucrose & BDO & $*$ & Koutinas et al. (2016) \\
\hline
\end{tabular}


increased the xylitol production. The enzymatic production of xylitol from a sugarcane bagasse hydrolysate, as an alternative to conventional fermentation route, was also studied and $100 \%$ conversion was reported due to direct transformation of xylose to xylitol (Sindhu et al., 2016). A study on xylitol production from sugarcane straw via the biochemical route revealed that the supplementation of an inorganic nitrogen source such as $\left(\mathrm{NH}_{4}\right)_{2} \mathrm{SO}_{4}$, was important for increasing the productivity of the process and the type of nutrients as well as control of the oxygen availability were also necessary for bioprocess production of xylitol from a sugarcane straw hydrolysate (Kamat et al., 2013). Co-production of xylitol with biodiesel or EtOH has also been studied. However, there is a lack of information on the economic assessment of different technologies associating with xylitol production from biomass, specifically sugarcane bagasse.

\subsection{Bio-based monomers and biopolymers}

Biopolymers are generally considered an eco-friendly alternative to petrochemical polymers due to the renewable feedstock consumption. Furthermore, biodegradable polymers such as PLA, poly-hydroxyalkanoates (PHAs), and starch-based polymers, have been examined as a solution for the future of our planet (Crank et al., 2004). Apart from biodegradability, production of some polymers with high volume consumption from bio-based monomers such as butadiene (BD) and butanediol (BDO) are advantageous (Mussatto and van Loosdrecht, 2016).

\subsubsection{Poly-lactic acid (PLA)}

PLA is made of lactic acid and can be produced from sugars via fermentation. PLA is applied in the form of a bio-based plastic alone, in blends with other polymers, or it can be reinforced with cellulose fibres, mostly in packaging industry and textiles. There are three main methods available to produce PLA from LA including, 1) direct condensation polymerization, 2) direct polycondensation in an azeotropic solution, and 3) polymerization via lactide formation (Castro-Aguirre et al., 2016). Although several studies have considered LA production from sugarcane, PLA production is typically not included.

\subsubsection{Poly-hydroxyalkanoates (PHAs)}

PHAs are linear polyesters produced in nature by direct bacterial fermentation of sugars or lipids. They are produced by the bacteria to store carbon and energy, usually under conditions of physiological stress. A generic process for PHAs produced by bacterial fermentation consists of three basic steps namely fermentation, isolation, and purification followed by blending and palletising (Crank et al., 2004). Although PHAs have attracted widespread interests as alternatives to conventional plastics, their $20-80 \%$ higher production cost compared with petrochemical plastics is the key bottleneck (Fernández-Dacosta et al., 2015). Three main factors contribute to this relatively high production costs of PHAs: (i) the energy required for the sterilisation of the fermentation equipment, (ii) the PHAs yield on the substrate, and (iii) the efficiency of the downstream processing (Fernández-Dacosta et al., 2015). Therefore, cheap substrate such as industrial wastewater or activated slug could be promising (Mudliar et al., 2008). The study by Moncada et al. (2013) is one of the rare studies evaluating sugarcane molasses and juice for PHAs production. More specifically, they conducted a techno-economic analysis for a sugarcane biorefinery for different conversion pathways as function of feedstock distribution and technologies for sugar, fuel ethanol, polyhydroxybutyrate (PHB) (a common type of PHAs), anthocyanins, and electricity production. Their results showed that the best economic performance was achieved in a biorefinery producing fuel ethanol and PHB from combined cane bagasse and molasses (Moncada et al., 2013).

\subsubsection{Butanediol (BDO)}

BDO (1,4-butanediol or 2,3-butanediol) is a four-carbon primary alcohol, considered as a building block for the production of polymers, solvents, and specialty chemicals. Current demands for BDO is just under 2 million metric $\mathrm{t} / \mathrm{y}$. Genomatica has successfully demonstrated an integrated process for BDO production utilizing a range of lignocellulosic sugars that has a commercialization potential. Catalytic conversion of succinic acid to BDO is another promising conversion strategy, currently being scaled-up (Biddy et al., 2016). Koutinas et al. (2016) studied techno-economic evaluation of 2,3-butanediol production via fermentation, using glycerol, sucrose, and sugarcane molasses as carbon sources. They found that MSP varied from 2.6 to $4.8 \mathrm{USD} / \mathrm{kg}$ sugarcane molasses, based on the variation of molasses' price and fixed capital requirement. Considering the market price of BDO reported as $1,800 \mathrm{USD} / \mathrm{t}$ to 3,200 USD/t in the year 2013 (Taylor et al. 2015), this process has the potential to be economically profitable.

\subsubsection{Butadiene $(B D)$}

BD (1,3-butadiene) is one of the major building blocks used in the production of synthetic rubbers and polymers (Ochoa et al., 2016), with a global demand of 10 million $t$ in the year 2012 (Makshina et al., 2014) and a rapid production growth, specifically in Asia (Sushkevich et al., 2015; Cespi et al., 2016). Polybutadiene (PBR) and styrene-butadiene rubber (SBR) are the main end applications for BD including 54\% of total usage in the year 2014. Nowadays, the dominant technology for the production of BD is thermal cracking of naphtha, while catalytic and oxidative dehydrogenation of n-butane is also used on industrial scale (White, 2007) Nevertheless, naphtha still represents the primary material for BD production (55\%), followed by ethane (30\%) (Cespi et al., 2016). An alternative approach is the production of $\mathrm{BD}$ from $\mathrm{EtOH}$ applying one-stage (Lebedev) process or two-stage (Ostromisslensky) process. Considering the possibility of EtOH production from $1 \mathrm{G}$ and $2 \mathrm{G}$ feedstocks, produced $\mathrm{BD}$ can be assumed as bio-BD. Farzad et al. (2017b) have developed different scenarios for $2 \mathrm{G}$ biorefineries annexed to a sugar mill for BD production via a two-step process. Monte Carlo financial risk analysis demonstrated that $\mathrm{BD}$ production could be profitable, only if the average of ten-year historical price would increase by 1.9 fold (Farzad et al., 2017b).

\section{Conclusions}

The environmental challenges and depleting fossil fuel resources necessitate the transition toward bio-based economy. Sugar mills have the opportunities to become biorefineries, based on several feedstock conversion potentials. The easiest of these would be sugars/molasses conversion via the biochemical route, while newer $2 \mathrm{G}$ technologies for lignocelluloses conversion are also becoming a commercial reality $\mathrm{EtOH}$ LA, etc.). To emphasise on this possibility, the most recent studies on production of some biofules/biochemical/biopolymers from sugarcane bagasse have been reviewed in this study. Overall, it should be stressed that TEA remains essential to sift through the multitude of technology/product options, and to identify specific product/investment opportunities applicable to specific sugar mills.

\section{References}

[1] Albarelli, J.Q., Onorati, S., Caliandro, P., Peduzzi, E., Meireles, M.A.A., Marechal, F., Ensinas, A.V., 2015. Multi-objective optimization of a sugarcane biorefinery for integrated ethanol and methanol production. Energy. https://doi.org/10.1016/j.energy.2015.06.104

[2] Alves, C.M., Valk, M., de Jong, S., Bonomi, A., van der Wielen, L.A., Mussatto, S.I., 2017. Techno-economic assessment of biorefinery technologies for aviation biofuels supply chains in Brazil. Biofuels, Bioprod. Biorefin. 11(1), 67-91.

[3] Baeyens, J., Kang, Q., Appels, L., Dewil, R., Lv, Y., Tan, T., 2015. Challenges and opportunities in improving the production of bioethanol. Prog. Energy Combust. Sci. 47, 60-88.

[4] Balan, V., Chiaramonti, D., Kumar, S., 2013. Review of US and EU initiatives toward development, demonstration, and commercialization of lignocellulosic biofuels. Biofuels, Bioprod. Biorefin. 7(6), 732-759.

[5] Bezerra, T.L., Ragauskas, A.J., 2016. A review of sugarcane bagasse for second-generation bioethanol and biopower production. Biofuels, Bioprod. Biorefin. 10(5), 634-647.

[6] Bhutto, A.W., Qureshi, K., Abro, R., Harijan, K., Zhao, Z., Bazmi, A.A., Abbas, T., Yu, G., 2016. Progress in the production of 
biomass-to-liquid biofuels to decarbonize the transport sector-prospects and challenges. RSC Adv. 6(38), 32140-32170.

[7] Biddy, M.J., Scarlata, C., Kinchin, C., 2016. Chemicals from biomass: A market assessment of bioproducts with near-term potential (No. NREL/TP--5100-65509). National Renewable Energy Laboratory (NREL)

[8] Bos, H.L., Sanders, J.P., 2013. Raw material demand and sourcing options for the development of a bio-based chemical industry in Europe. Biofuels, Bioprod. Biorefin. 7(3), 246-259.

[9] Bozzano, G., Manenti, F., 2016. Efficient methanol synthesis: perspectives, technologies and optimization strategies. Prog. Energy Combust. Sci. 56, 71-105.

[10] Brown, T.R., 2015. A techno-economic review of thermochemical cellulosic biofuel pathways. Bioresour. Technol. 178, 166-176.

[11] Castro-Aguirre, E., Iñiguez-Franco, F., Samsudin, H., Fang, X., Auras, R., 2016. Poly (lactic acid)-Mass production, processing, industrial applications, and end of life. Adv. Drug Delivery Rev. 107, 333-366.

[12] Cespi, D., Passarini, F., Vassura, I., Cavani, F., 2016. Butadiene from biomass, a life cycle perspective to address sustainability in the chemical industry. Green Chem. 18(6), 1625-1638

[13] Chum, H.L., Warner, E., Seabra, J.E., Macedo, I.C., 2014. A comparison of commercial ethanol production systems from Brazilian sugarcane and US corn. Biofuels, Bioprod. Biorefin. 8(2), 205-223.

[14] Clauser, N.M., Gutiérrez, S., Area, M.C., Felissia, F.E., Vallejos, M.E., 2016. Small-sized biorefineries as strategy to add value to sugarcane bagasse. Chem. Eng. Res. Des. 107, 137-146.

[15] Crank, M., Patel, M., Marscheider-Weidemann, F., Schleich, J., Hüsing, B., Angerer, G., 2004. Techno-economic feasibility of large-scale production of bio-based polymers in Europe (PRO-BIP). Final report (No. NWS-E--2004-111). Department of Science.

[16] Dang, Q., Hu, W., Rover, M., Brown, R.C., Wright, M.M., 2016. Economics of biofuels and bioproducts from an integrated pyrolysis biorefinery. Biofuels, Bioprod. Biorefin. 10(6), 790-803

[17] Dias, M.O., Junqueira, T.L., Cavalett, O., Pavanello, L.G., Cunha, M.P., Jesus, C.D., Maciel Filho, R., Bonomi, A., 2013a. Biorefineries for the production of first and second generation ethanol and electricity from sugarcane. Appl. Energy. 109, 72-78.

[18] Dias, M.O., Junqueira, T.L., Cavalett, O., Cunha, M.P., Jesus, C.D., Mantelatto, P.E., Rossell, C.E., Maciel Filho, R., Bonomi, A., 2013b. Cogeneration in integrated first and second generation ethanol from sugarcane. Chem. Eng. Res. Des. 91(8), 1411-1417.

[19] Dias, M.O., Pereira, L.G., Junqueira, T.L., Pavanello, L.G., Chagas, M.F., Cavalett, O., Maciel Filho, R., Bonomi, A., 2014. Butanol production in a sugarcane biorefinery using ethanol as feedstock. Part I: Integration to a first generation sugarcane distillery. Chem. Eng. Res. Des. 92(8), 1441-1451.

[20] Dias, M.O., Maciel Filho, R., Mantelatto, P.E., Cavalett, O., Rossell, C.E.V., Bonomi, A., Leal, M.R.L.V., 2015. Sugarcane processing for ethanol and sugar in Brazil. Environmen. Dev. 15, 35-51.

[21] Diederichs, G.W., Mandegari, M.A., Farzad, S., Görgens, J.F., 2016. Techno-economic comparison of biojet fuel production from lignocellulose, vegetable oil and sugar cane juice. Bioresour. Technol. 216, 331-339

[22] Farzad, S., Mandegari, M.A., Görgens, J.F., 2016. A critical review on biomass gasification, co-gasification, and their environmental assessments. Biofuel Res. J. 3(4), 483-495.

[23] Farzad, S., Mandegari, M.A., Guo, M., Haigh, K.F., Shah, N., Görgens, J.F., 2017a. Multi-product biorefineries from lignocelluloses: a pathway to revitalisation of the sugar industry?. Biotechnol. Biofuels. 10(1), 87.

[24] Farzad, S., Mandegari, M.A., Görgens, J.F., 2017b. Integrated technoeconomic and environmental analysis of butadiene production from biomass. Bioresour. Technol. 239, 37-48

[25] Fernández-Dacosta, C., Posada, J.A., Kleerebezem, R., Cuellar, M.C., Ramirez, A., 2015. Microbial community-based polyhydroxyalkanoates (PHAs) production from wastewater: techno-economic analysis and exante environmental assessment. Bioresour. Technol. 185, 368-377.

[26] FitzPatrick, M., Champagne, P., Cunningham, M.F., Whitney, R.A., 2010. A biorefinery processing perspective: treatment of lignocellulosic materials for the production of value-added products. Bioresour. Technol. 101(23), 8915-8922.
[27] Gao, C., Ma, C. , Xu, P., 2011. Biotechnological routes based on lactic acid production from biomass. Biotechnol. Adv. 29(6), 930939.

[28] Gubicza, K., Nieves, I.U., Sagues, W.J., Barta, Z., Shanmugam, K.T., Ingram, L.O., 2016. Techno-economic analysis of ethanol production from sugarcane bagasse using a Liquefaction plus Simultaneous Saccharification and co-Fermentation process. Bioresour. Technol. 208, 42-48.

[29] Huang, H.J., Yuan, X.Z., 2015. Recent progress in the direct liquefaction of typical biomass. Prog. Energy Combust. Sci. 49, 59 80 .

[30] Jiang, Y., Liu, J., Jiang, W., Yang, Y., Yang, S., 2015. Current status and prospects of industrial bio-production of n-butanol in China. Biotechnol. Adv. 33(7), 1493-1501.

[31] Jin, C., Yao, M., Liu, H., Chia-fon, F.L., Ji, J., 2011. Progress in the production and application of n-butanol as a biofuel. Renew. Sust. Energy Rev. 15(8), 4080-4106

[32] Kamat, S., Khot, M., Zinjarde, S., RaviKumar, A., Gade, W.N. 2013. Coupled production of single cell oil as biodiesel feedstock, xylitol and xylanase from sugarcane bagasse in a biorefinery concept using fungi from the tropical mangrove wetlands. Bioresour. Technol. 135, 246-253.

[33] Klein-Marcuschamer, D., Turner, C., Allen, M., Gray, P., Dietzgen, R.G., Gresshoff, P.M., Hankamer, B., Heimann, K., Scott, P.T., Stephens, E., Speight, R., 2013. Technoeconomic analysis of renewable aviation fuel from microalgae, Pongamia pinnata, and sugarcane. Biofuels, Bioprod. Biorefin. 7(4), 416-428

[34] Koutinas, A.A., Vlysidis, A., Pleissner, D., Kopsahelis, N., Garcia, I.L., Kookos, I.K., Papanikolaou, S., Kwan, T.H., Lin, C.S.K., 2014. Valorization of industrial waste and by-product streams via fermentation for the production of chemicals and biopolymers. Chem. Soc. Rev. 43(8), 2587-2627.

[35] Koutinas, A.A., Yepez, B., Kopsahelis, N., Freire, D.M., de Castro, A.M., Papanikolaou, S., Kookos, I.K., 2016. Techno-economic evaluation of a complete bioprocess for 2, 3-butanediol production from renewable resources. Bioresour. Technol. 204, 55-64.

[36] Lange, J.P., 2007. Lignocellulose conversion: an introduction to chemistry, process and economics. Biofuels, Bioprod. Biorefin. 1(1), 39-48.

[37] Luo, L., van der Voet, E., Huppes, G., 2010. Biorefining of lignocellulosic feedstock-Technical, economic and environmental considerations. Bioresour. Technol. 101(13), 5023-5032.

[38] Macrelli, S., Mogensen, J., Zacchi, G., 2012. Techno-economic evaluation of $2^{\text {nd }}$ generation bioethanol production from sugar cane bagasse and leaves integrated with the sugar-based ethanol process. Biotechnol. Biofuels. 5(1), 22.

[39] Makshina, E.V., Dusselier, M., Janssens, W., Degreve, J., Jacobs, P.A., Sels, B.F., 2014. Review of old chemistry and new catalytic advances in the on-purpose synthesis of butadiene. Chem. Soc. Rev. 43(22), 7917-7953.

[40] Mandegari, M.A., Farzad, S., Görgens, J.F., 2017a. Economic and environmental assessment of cellulosic ethanol production scenarios annexed to a typical sugar mill. Bioresour. Technol. 224, 314-326.

[41] Mandegari, M.A., Farzad, S., van Rensburg, E., Görgens, J. F. 2017b. Multi criteria analysis of a biorefinery for co- production of lactic acid and ethanol from sugarcane lignocellulose. Biofuels Bioprod Biorefin. (10.1002/bbb.1801).

[42] Mariano, A.P., Dias, M.O., Junqueira, T.L., Cunha, M.P., Bonomi, A., Maciel Filho, R., 2013. Butanol production in a first-generation Brazilian sugarcane biorefinery: technical aspects and economics of greenfield projects. Bioresour. Technol. 135, 316-323.

[43] Mawhood, R., Gazis, E., de Jong, S., Hoefnagels, R., Slade, R., 2016. Production pathways for renewable jet fuel: a review of commercialization status and future prospects. Biofuels, Bioprod. Biorefin. 10(4), 462-484

[44] Michailos, S., Parker, D., Webb, C., 2017. A techno-economic comparison of Fischer-Tropsch and fast pyrolysis as ways of utilizing sugar cane bagasse in transportation fuels production. Chem. Eng. Res. Des. 118, 206-214. 
[45] Mohamad, N.L., Mustapa Kamal, S.M., Mokhtar, M.N., 2015. Xylitol biological production: a review of recent studies. Food Rev. Int. 31(1), 74-89.

[46] Moncada, J., El-Halwagi, M.M., Cardona, C.A., 2013. Technoeconomic analysis for a sugarcane biorefinery: Colombian case. Bioresour. Technol. 135, 533-543.

[47] Mudliar, S.N., Vaidya, A.N., Kumar, M.S., Dahikar, S., Chakrabarti, T., 2008. Techno-economic evaluation of PHB production from activated sludge. Clean Technol. Environ. Policy. 10(3), 255.

[48] Mussatto, S.I., van Loosdrecht, M., 2016. Cellulose: a key polymer for a greener, healthier, and bio-based future. Biofuel Res. J. 3(4), 482-482.

[49] Ndaba, B., Chiyanzu, I., Marx, S., 2015. n-Butanol derived from biochemical and chemical routes: a review. Biotechnol. Rep. 8, 1-9.

[50] Nsaful, F., Görgens, J.F., Knoetze, J.H., 2013. Comparison of combustion and pyrolysis for energy generation in a sugarcane mill. Energy Convers. Manage. 74, 524-534.

[51] Ochoa, J.V., Bandinelli, C., Vozniuk, O., Chieregato, A., Malmusi, A., Recchi, C., Cavani, F., 2016. An analysis of the chemical, physical and reactivity features of $\mathrm{MgO}-\mathrm{SiO} 2$ catalysts for butadiene synthesis with the Lebedev process. Green Chem. 18(6), 1653-1663.

[52] Oliveira, F.M., Pinheiro, I.O., Souto-Maior, A.M., Martin, C., Gonçalves, A.R., Rocha, G.J., 2013. Industrial-scale steam explosion pretreatment of sugarcane straw for enzymatic hydrolysis of cellulose for production of second generation ethanol and value-added products. Bioresour. Technol. 130, 168-173.

[53] Parajuli, R., Dalgaard, T., Jørgensen, U., Adamsen, A.P.S., Knudsen, M.T., Birkved, M., Gylling, M., Schjørring, J.K., 2015. Biorefining in the prevailing energy and materials crisis: a review of sustainable pathways for biorefinery value chains and sustainability assessment methodologies. Renew. Sust. Energy Rev. 43, 244-263.

[54] Peplow, M., 2014. Cellulosic ethanol fights for life. Nature. 507(7491), 152.

[55] Pereira, L.G., Dias, M.O.S, Junqueira, T.L., Pavanello, L.G., Chagas, M.F., Cavalett, O., Maciel Filho, R., Bonomi, A., 2014. Butanol production in a sugarcane biorefinery using ethanol as feedstock. Part II: Integration to a second generation sugarcane distillery. Chem. Eng. Res. Des. 92(8), 1452-1462.

[56] Pereira, L.G., Dias, M.O.S., Mariano, A.P., Maciel Filho, R., Bonomi, A.M.F.L.J., 2015. Economic and environmental assessment of n-butanol production in an integrated first and second generation sugarcane biorefinery: fermentative versus catalytic routes. Appl. Energy. 160, 120-131.

[57] Petersen, A.M., Aneke, M.C., Görgens, J.F., 2014. Techno-economic comparison of ethanol and electricity coproduction schemes from sugarcane residues at existing sugar mills in Southern Africa. Biotechnol. Biofuels. 7(1), 105.

[58] Petersen, A.M., Farzad, S., Görgens, J.F., 2015. Techno-economic assessment of integrating methanol or Fischer-Tropsch synthesis in a South African sugar mill. Bioresour. Technol. 183, 141-152.

[59] Renó, M.L.G., del Olmo, O.A., Palacio, J.C.E., Lora, E.E.S., Venturini, O.J., 2014. Sugarcane biorefineries: case studies applied to the Brazilian sugar-alcohol industry. Energy Convers. Manage. 86, 981-991.

[60] Sánchez, Ó.J., Cardona, C.A., 2012. Conceptual design of cost-effective and environmentally-friendly configurations for fuel ethanol production from sugarcane by knowledge-based process synthesis. Bioresour. Technol. 104, 305-314.

[61] Santos, C.I., Silva, C.C., Mussatto, S.I., Osseweijer, P., van der Wielen, L.A., Posada, J.A., 2017. Integrated $1^{\text {st }}$ and $2^{\text {nd }}$ generation sugarcane biorefinery for jet fuel production in Brazil: Techno-economic and greenhouse gas emissions assessment. Renew. Energy. https://doi.org/10.1016/j.renene.2017.05.011

[62] Seabra, J.E., Tao, L., Chum, H.L., Macedo, I.C., 2010. A technoeconomic evaluation of the effects of centralized cellulosic ethanol and co-products refinery options with sugarcane mill clustering. Biomass Bioenergy. 34(8), 1065-1078.

[63] Seabra, J.E., Macedo, I.C., 2011. Comparative analysis for power generation and ethanol production from sugarcane residual biomass in Brazil. Energy Policy. 39(1), 421-428.
[64] Shamsul, N.S., Kamarudin, S.K., Rahman, N.A., Kofli, N.T., 2014 An overview on the production of bio-methanol as potential renewable energy. Renew. Sust. Energy Rev. 33, 578-588.

[65] Sindhu, R., Gnansounou, E., Binod, P., Pandey, A., 2016 Bioconversion of sugarcane crop residue for value added productsan overview. Renew. Energy. 98, 203-215.

[66] Smithers, J., 2014. Review of sugarcane trash recovery systems for energy cogeneration in South Africa. Renew. Sust. Energy Rev. 32, 915-925.

[67] Sushkevich, V.L., Ivanova, I.I., Taarning, E., 2015. Ethanol conversion into butadiene over $\mathrm{Zr}$-containing molecular sieves doped with silver. Green Chem. 17(4), 2552-2559.

[68] Tan, E.C., Talmadge, M., Dutta, A., Hensley, J., Schaidle, J., Biddy, M., Humbird, D., Snowden-Swan, L.J., Ross, J., Sexton, D., Yap, R., 2015. Process design and economics for the conversion of lignocellulosic biomass to hydrocarbons via indirect liquefaction. thermochemical research pathway to high-octane gasoline blendstock through methanol/dimethyl ether intermediates (No. NREL/TP-5100-62402). National Renewable Energy Laboratory (NREL).

[69] Taylor, R., Nattrass, L., Alberts, G., Robson, P., Chudziak, C., Bauen, A., Libelli, I.M., Lotti, G., Prussi, M., Nistri, R., Chiaramonti, D., 2015. From the sugar platform to biofuels and biochemicals: final report for the European Commission DirectorateGeneral Energy.

[70] Wang, W.C., Tao, L., 2016. Bio-jet fuel conversion technologies. Renew. Sust. Energy Rev. 53, 801-822.

[71] White, W.C., 2007. Butadiene production process overview. Chem. Biol. Interact. 166(1), 10-14. 